\title{
Thinking from No-Man's-Land. The Life and Work of Theodor W. Adorno
}

\author{
by Stefan Müller-Doohm \\ translated by Stefan Bird-Pollan
}

First Published in Studies in Social and Political Thought 11, 2005.

September Eleventh of 2003 was commemorated around the world as a special day because it was the centenary of the birthday of Theodor W. Adorno: the philosopher of determinate negation, who, like no other, called into question the institutions of the world as a systems of horror. If, on the occasion of this anniversary, I take it upon myself as a witness of the $21^{\text {st }}$ Century to describe aspects of Adorno's critical social and cultural theory, and want at the same time to sketch a portrait of its creator, I must replace the aforementioned image of Adorno with another one. The coincidence of the dates 11 September 1903 and 11 September 2001 creates a certain distorted interaction between the two events. The idiosyncratic consciousness of time demanded by Adorno forces us to register the coincidence of the date of his birth and the date on which terrorists caused a terrible mass murder: the strategic and intentional murder of innocent people in order to cause collective panic. This coincidence only further emphasizes the fact that it was Adorno who posed the most pressing of questions, one that still remains to be answered today. 'Why does humanity enter into a new barbarism instead of entering into a truly human condition?' (Horkheimer and Adorno, 1973: xi).

Adorno, who formulated these lines more than 50 years ago with Max Horkheimer, was thinking of totalitarianism and genocide, the bureaucratic, state organized, and industrially conducted killing of six million Jews. Fanatical terrorism, like the world war against international terrorism waged by a super-power, now called for and already acted upon, shows that there is in fact no end to violence. As Adorno noted in the mid-forties in his reflection on the course of history, life is indeed an endless succession of shocks. Thus the extreme formulation found in Dialectic of Enlightenment is still accurate: 'The fully enlightened earth glows under the sign of triumphal 
devastation' (1973: 3).

I exaggerate intentionally by bringing Dialectic of Enlightenment, a book which is concerned with the rise and fall of reason, to bear on this contemporary threat: for the man born 100 years ago belonged to that small group of intellectuals who set themselves the pressing task of comprehending an absurd world from whose lap the miscarriage of perpetual violence still continues to issue. "That it continues "as it is", this is the catastrophe' (Benjamin, 1999: 473). The thinking of Adorno, Horkheimer and Benjamin had to show itself capable of sustaining this thought.

For, do we really have occasion to deny what Adorno noted in his 'dialogue intérieur' from his American exile in 1944?

There is nothing harmless anymore.... Even the tree which blossoms lies in that moment in which one perceives its blossoms without the shadow of horror; even the innocent 'how nice' becomes an excuse for the suffering of existence, which is different, and there is no beauty and no solace but in the gaze, which sees horror, suffers it and, in the unmitigated consciousness of negativity, holds fast to the possibility of something better. (Adorno, 1974: 25)

This quotation, illustrating as it does Adorno's linguistic virtuosity (he was one of the most linguistically adept writers of the last century), leads to the core of his intransigent philosophical style of thought, his negativism and his utopianism.

Adorno, born shortly after the turn of the last century, already as a young man witnessed the fragmentary nature of modernity, the exhaustion of the bourgeois-humanist canon of form, the crisis and failure of intellectual and aesthetic values, as well as the emergence of an ever more radical artistic avant-garde. As a thirty year old, Adorno witnessed history's descent into a catastrophe, whose victim he too would become. How does a sensitive person react to this experience of history, to the real experience of apocalypse and its exaggeration in art. In searching for an answer, Adorno was never drawn to nihilism, but instead looked to reason. Reason is for him autonomous and must pull itself out of the morass by its own hair. It can only sustain itself 'in desperation and overflow.' (1974: 200) The insight that the dialectic 'moves through the extremes and thus brings thought to turn in on itself in its most extreme consequence' (1974: 86) is a central tenet of Adorno's philosophy. In following this thought, Adorno's philosophy concerns itself with reason's dissonance and free atonality which extends well beyond the realm of music. 
Adorno was known as a heretical and non-conformist intellectual for whom 'the capacity for fear and for happiness' (1974: 200) are subjective qualities, which apply equally to his own personality. This is one side of the philosopher, sociologist, music-, literary- and cultural- critic. But it is not Adorno in his entirety. There is also the other side, that of the musician and the composer whose more than thirty musical works were created in the most diverse genres, from piano songs to pieces for orchestra and choirs. His is a musical corpus whose stylistic orientation is close to Schönberg, Webern and Alban Berg, but which refuses dogmatic gestures. It is close-knit and lyrical rather than dramatic in manner.

Adorno lived many lives: that of a sheltered and precocious single child in the commercially successful and intellectually engaged house of his parents, that of a left intellectual in the Weimar era, that of a German émigré in England and the United States and finally, that of an influential social critic in post-war Germany. But he loved the life of the artist most, a life which for him was embodied by his deeply beloved mother; before her marriage to the assimilated Jew, the wine exporter Oskar Wiesengrund, his mother, Maria Cavelli-Adorno, had had a successful career as an opera singer in Vienna, Cologne, Prague and Riag and elsewhere. She even accompanied the famous Italian singer Adelina Patti on her US-tour for a short time. Adorno's second mother, his mother's unmarried sister, who also lived in the Wiesengrund household, took it upon herself to educate her nephew in things musical and literary as well - to this end she sang Schubert, played Haydn and Brahms piano pieces for four hands with her nephew and read Baudelaire in the original with him. Adorno grew up in a world of music and literature in which it was not unsurprising that he, for instance, impressed his family with renditions of Beethoven at the age of twelve. While the Jewish tradition receded to the background, mother and aunt made sure that the youngster, who was baptized in the Frankfurt cathedral and confirmed as a schoolboy, was exposed to the world of Catholic symbols and images.

His father, Oskar Alexander Wiesengrund, did not interfere with his son's education. When, on occasion, he did express his values to his son, he did so without invoking patriarchal authority or giving the appearance of being a stern despot. As an assimilated Jew and an economically successful wine merchant, Oskar Wiesengrund had a cosmopolitan outlook. The comfortable position of the socially esteemed business man made it easier for Adorno to identify both with the internal orientation of the ideals of his mother and with the character and values of his father. It is interesting to note that, both as a youth and as an adult, Adorno sought proximity to men, who, from time to time, became father figures. This was the case in his 
complicated but enduring friendship with the intellectual outsider Siegfried Kracauer as well as in his close relationship to the composer Alban Berg and with the philosopher Walter Benjamin, but most of all in the intense bond with Max Horkheimer.

The intellectually challenging and happy childhood Adorno enjoyed was part of the basis for the specifically utopian current in his later philosophical thought; he would later claim that the aptitude for utopia 'feeds on the love for mother' (1974: 23). Adorno's writings are replete with references back to the positive experiences of his childhood: he himself speaks of 'memory traces of childhood, which made it seem as if it were worthwhile to live for them alone' (1974: 200).

At school, 'Teddie' had the reputation of being an overachiever, if not a 'Wunderkind.' At age 16, he enthusiastically read Theory of the Novel by Georg Lukács as well as Ernst Bloch's Spirit of Utopia. He was an avid reader of books and musical scores alike. With the help of his older friend Siegfried Kracauer, he began at this time to read Kant's Critique of pure Reason, and later Kierkegaard and Hegel. He left gymnasium at the age of 17 as the best student of the class.

Adorno completed his studies with a dissertation on Husserl at the unconventional and liberal University of Frankfurt before moving to Vienna to study composition with Alban Berg. The months the young Adorno spent in Vienna, the city of music par excellence, and especially his friendship with Alban Berg, whom he calls 'Lord and Master' in letters, left a deep impression not only on his understanding of music but on his personality. In Vienna he becomes part of the second Vienna school, he meets the authors Karl Kraus and Soma Morgenstern, the philosopher Georg Lukács, as well as Alma Mahler and her third husband, the author Franz Werfel. In Vienna the twenty-one-year-old learns to appreciate the sensuous pleasures of life like good food and fine wine. But the city also fascinates him because of its insistent anti-traditionalism in the face of a great tradition.

Although Adorno makes a name for himself as a music critic toward the end of the twenties, he decides to become an assistant professor for philosophy at the University of Frankfurt. He already impresses people with his intellectual acuity and wide learning. But he becomes a critical intellectual only as the result of the historically specific experience of national socialism and his own exile. The race laws make the left intellectual Adorno into a Jew, and thus into an outsider.

Adorno's thinking is politicized and radicalized by his forced emigration, first to England and then to the United States. His thinking achieves autonomous significance as a dialectical critique of society only in the years of exile. By reflecting on his own, existential and intentional (Hans 
Mayer) outsider status, Adorno grasps exile as the mark of an entire epoch. His description of himself to Thomas Mann as 'professionally [as well as nationally] without a home [Heimat]' shows that Adorno equates his experience of exile with the general outsider position of the intellectual.

Adorno gives a trenchant assessment of the devastating course of history in Reflections from a Damaged Life. In these Minima Moralia Adorno contemplates the loss of culture and language in exile as well as the exile's uncertain status between safety and foreignness. Minima Moralia expresses that mourning and desperation which the author associates with his own existential and intentional loss of a home. In the dedication to this collection of aphorisms (which Habermas rightly claims can be studied as a philosophical masterpiece) Adorno informs the reader of the method of his 'mournful science.' The historical collapse of the 'old subject' notwithstanding, all observation of the world must originate in individual experience. The condition of society can best be seen in individual experience,' even if subjective observation has thing 'sentimental and anachronistic' about it (Adorno, 1992: 145). In this way these very personal writings express on the one side that in exile Adorno felt himself excluded from society. The feeling of deracination, however, also brings with it a moment of autonomy and freedom. Through his own marginalization, Adorno experienced the double position in society of the social critic who is at once in society but not quite integrated in it. From this extraterritorial realm of the no-man's-land, Adorno is able to observe social life. His vehement criticism of the then current forms of American culture notwithstanding, Adorno never favorably contrasts the past bourgeois forms of [European] education and high culture with the leveling pressures to conform of the US society in which he lived. On the contrary, he emphasized that the qualities of bourgeois forms of life had long ago revealed their other side:

Whatever was once good and upstanding about the bourgeoisie, its independence, tenacity, foresight, perspicacity has become spoiled to the core. For, while bourgeois forms of existence are doggedly preserved, their economic preconditions have disappeared. The private has become the privative, which it secretly always was. Anger has mingled with the obdurate insistence by each person on their own interests, so that it has really ceased to be possible to notice that things might be different and better. The bourgeoisie has lost its innocence and has, as a result, become obstinate and angry about it. (Minima Moralia (tv): section 14: 34) 
In this, his most personal book, Adorno also articulated the shocking experience of Auschwitz for the first time. According to him the total dehumanization in the concentration camps is the expression of a society which makes all life into things. Everything which is particular or deviates was declared a 'mark of shame' for being different, and destroyed. Through this the exponentially increasing socialization, society itself generates a will to destroy. In this context, the idea of a right society is reduced to a life in which one can 'be different without fear' (1974: 16). For Adorno, however, the United States, where he not only found refuge and material survival, but led an eventful and happy life with his wife, Gretel, was apparently not the country in which one could live one's difference without fear. Was the assessment as social critic darkened because of his memory of Europe? There is something to this, for in a passage in Minima Moralia Adorno notes: 'Abroad every German deer roast tastes as if it has been killed by a hunter' (1974: 49). Ultimately Adorno's never ending longing for the lost Europe, in particular the desire to be able to express himself in German, was stronger than the attraction that Adorno and Gretel's life in California offered; here he was part of the Hollywood society which Berthold Brecht and Hanns Eisler, Lotte Lenja, Fritz Lang, Greta Garbo and Charlie Chaplin belonged. Adorno also had contact with Thomas Mann, who chose the philosopher of music to be 'general counsel' during the writing of his novel Doktor Faustus. Adorno was particularly proud of his work-relation with the 'very pleasant, friendly and cultured' author, as can be seen in the detailed reports about their cooperation in his letters to his parents. He writes to his mother that Thomas Mann, in a gesture of thanks for his music-theoretical counsel, 'composed' the name Wiesengrund into the novel 'in a highly artful way.' 'This is a delightful compensation for the loss of his proper Jewish name through the stupid pedantry of the US immigration officials.' Adorno here refers his American exile in which, during the process of naturalization, Theodor Ludwig Wiesengrund-Adorno had become Theodor Adorno. Henceforth, Adorno would publish under Theodor W. Adorno (Gödde and Lonitz, 2003a: 237, 431, 463ff, 524).

Five years after becoming a US citizen, in late fall of 1949, and 15 years after his own emigration, Adorno was, for the first time, able to see Europe and his own country now laid waste by war. The forty-six-year-old was devastated by his first contact with the European continent after his long years of exile. After arriving in Paris, where he stayed in the historic hotel 'Lutetia' on the Boulevard Raspail, he wrote to Max Horkheimer: 'The return to Europe has taken hold of me with a violence which I can scarcely put into words. And the beauty of Paris glimmers through the rags of poverty more movingly than ever before. [...] What is here may be historically condemned 
and carries the mark of this plainly enough, but that it still is, the uncontemporaneous itself, also belongs to the historical picture and carries with it the weak hope that something human has survived.' Adorno's spontaneous joy went so far that he altered the epigram to Minima Moralia and claimed that 'life still lives' (Horkheimer, 1996: 67).

The American citizen Adorno relates the impressions which he gathered of his native Frankfurt during the months 1949 to 1950 not only in many letters but also in his diary. Here he notes the conscientiousness of the students and writes to the author of Dr Faustus: 'The comparison to a Talmud-school suggests itself; sometimes it seems to me as if the spirits of the murdered Jews had gone over into the German intellectuals' (Gödde and Sprecher, 2002: 46).

It would not be long until Adorno was perceived as the prototype of that German intellectual who risked taking up taboo issues in a post-war Germany in the midst of rebuilding itself. Who but Adorno would have dared formulate the dictum: to write poetry after Auschwitz is barbaric. He thus exposed himself in a manner that would scarcely permit a return to the ivory tower of pure science. When, in late fall 1959, he finally turned to the question What does it mean: Working up the past? he was in the full spotlight of the public arena. As a philosopher and sociologist, Adorno used the reputation of his academic position to emphatically warn against the afterlife of national socialism. He claimed: 'l consider the afterlife of national socialism in democracy as potentially more threatening than the afterlife of fascist tendencies against democracy.'

During this time in which Adorno was among the few German intellectuals who were prepared to speak of the worst, Adorno became a moral authority for the generation which made history itself as sixtyeighters. It was Adorno who was able to grasp and articulate the generation's specific discomfort at the half-heartedness with which official Germany was coming to terms with the past. Adorno's rigorously critical stance was consonant with the ethical-political motivated sentiments of refusal which young intellectuals started to show toward society and state.

Let us return to the summer term 1962, and to the long and genuine applause which met Adorno as he walked to the podium in the packed Lecture room VI of the University of Frankfurt. His high forehead, the result of few remaining hairs and somewhat old-fashioned horn-rimmed glasses atop the round face leaves no doubt about the advanced age of the professor. The grey suit with buttoned vest and a slightly too bright tie - a bourgeois custom. But this should not deceive us about the anti-bourgeois thinking of the protagonist of critical social theory. Adorno clears his throat, removes his glasses, accidentally brushing the microphone causing a deafening sound 
which combines with the sharp rustle of his quickly jotted down notes. He glances at the few handwritten key words, fixes the now quiet audience with his lively big dark eyes which shoot out from behind his glasses, and begins the lecture. Adorno receives approval from his audience although he consistently refuses to make concessions in his lectures and seminars by simplifying the material, nor does he deign to deliver finished products of thought. Rather, he delivers his lectures as manifestations of a dialectical process of reflection which does not resolve contradictions but leaves them in tension. The movement of this process of reflection is effected by its own continued calling into question. Adorno's stylistic mannerisms, such as the habit of placing the reflective pronoun at end of the sentence, the frequent use of Latinate words as well as the use of the subjunctive, capture the audience as expressions of linguistic originality rather than being ironized as recognizable elements of style. The way in which Adorno questions outmoded beliefs and values proves to be one of the best schools for learning something about democracy as a cultural form of life in the first two decades of the Federal Republic.

Precisely because Adorno was perceived as an outsider who could be institutionally integrated no more than he could be classified to one academic discipline, he appeared as highly credible to his apostles. Whoever dares to postulate: 'There is no right life in falsehood,' can be trusted to have that speculative power of thought without which no counterproposal to current existence can be conceived. Adorno's critique of the totalizing system of exchange value in a capitalist economy, his critique of the progressing disintegration of the autonomous individual in the 'administrated world' and his critique of the primitive and omnipresent culture industry provided the decisive keywords for people to become conscious of the pathology of modernity.

As a refugee from the Nazis, Adorno was extended a great deal of confidence by the younger generation in postwar Germany. Adorno's criticism engaged the justified distrust against the glorification of German literature, German music and philosophy and opened up paths to Goethe, Beethoven and Kant. In his unconventional manner, Adorno placed this intellectual tradition in the context of an avant-garde. Thus he showed the younger generation how to move from Franz Kafka and Samuel Beckett to Stefan George and Rudolf Borchardt, from Schönberg and Webern to Bach and Mozart and from Marx and Freud to Kant, Hegel and Nietzsche. The growing hope, alive since the sixties that there was a 'different Germany' buried under the Nazi rubble which could be set free, can be credited in large part to Adorno's intellectual influence. Adorno's publishing campaign for an 'education to maturity [Mündigkeit]' had almost revolutionary 
ramifications for pedagogy and proved to be the impetus for the school and university reform of the seventies.

Nonetheless, it was never Adorno's intention to claim the hybrid role of chief intellectual for himself. He tries to open people's eyes to the fact that the common need for ready frameworks comes burdened with conformist substantive content, where there cannot be any substantive content. It thus became clear that only autonomous thinking and acting can stand against 'fundamental values.'

There were several rumors about Adorno's private life. In particular, his passion for the female sex was reported on often, but usually without malice. He was easily made passionate by women while at the same time being an old-school gentleman, who kissed hands as a matter of common courtesy; even in situations where this form of courtliness perhaps appeared comical. He dedicated some of his books and articles to the not insignificant number of women to whom he stood in a special relation.

Adorno was always open to the needs of students. Even later, in the course of the increasing politicization of student movements, he, together with the younger Jürgen Habermas, was one of the professors who were prepared to engage in discussions about the reform of the university, the US policy in Vietnam or the emergency laws proposed by the German parliament. Despite his sharp criticism of some of the actions of parts of the antiauthoritarian protest movement, Adorno stayed in contact with left groups who, for their part, engaged with Adorno's criticism of capitalism.

Even if the rigor of his statements has something elitist and the tone of his texts had something apodictic about them, the professorial disease of cynicism was foreign to him. He was a highly sensitive man who always tried to avoid false intimacy even in relations with friends. He tried to overcome his shyness with a mixture of distance and conventional politeness. To Hans Magnus Enzensberger, who lived in Frankfurt's Westend in the time around 1960 and was a close neighbor, Adorno evinced a 'Chinese politeness and reserve.' Enzensberger reports: 'getting close to Adorno was not exactly easy. He had so many layers of protection around him that interaction with him had something ceremonial about it .... We saw each other often, but the distance was always maintained .... When one was with Adorno, one always felt a little stupid, for he was of monstrous intelligence' (Enzensberger, 1999).

Despite his public influence in the sixties and his publishing successes as an author of books about Gustav Mahler, of Jargon of Authenticity and of Negative Dialectics, Adorno remained what he had always been: an outsider. A sign of this is that philosophy belittled him as a sociologist, sociologists called him too philosophical, the academics thought of him as an essayist 
and artist while artists thought he was too abstract and theoretical. Ostensibly bourgeois, Adorno was the sharpest critic of his own class: 'Whatever was once good and upstanding about the bourgeoisie ... has become spoilt to the core.' Because Adorno had been aware of the shoddy edifice of the bourgeois tradition, and had let himself be guided by the idea that the 'marks of disruption [are] ... modernity's mark of authenticity,' his interest turned to those writers who thematized the demise of the bourgeois world. The unbourgeois qualities which Adorno discerns in his portrait of Thomas Mann, the highly esteemed epigone of educated bourgeois, are partly themselves disguised self-descriptions: the antinome between bourgeois existence and the life of the artist, the discontinuity of his path of life, the pairing of self-motivation with the readiness to be alone. The longing for applause held for Adorno as well, who might also have said of himself: 'He was almost defenselessly and without armor exposed to the affect of joy and that of pain' (Adorno, 1992: 18).

Like no other, Adorno knew that the intellectual is only able to maintain solidarity in uninterrupted loneliness. Already in a letter from the summer of 1937, during his emigration years in England, he told Horkheimer that he was a writer of a particular kind: 'one whose a priori it is to inflict upon himself the deepest loneliness and the principal impossibility of what he thinks and says' (Gödde and Lonitz, 2003b: 374). Adorno characterizes those citizens as intellectuals who refuse to be dominated by the bourgeoisie: intellectuals are the last bourgeois citizens and at the same time, their enemies.

Ever since his inaugural lecture of 1931 as assistant professor for philosophy, the critique of the process of knowing had been central to what he called 'the same in divergent realms' in a letter to Thomas Mann: ${ }^{1}$ to analyze reality under the aspect of its incompleteness. Adorno characterizes this practice of knowing as a dialectical movement in which the negation of negation does not issue in positivity.

With this epistemic goal, Adorno reacted against the type of dialectics which, according to him, has an affirmative basis in philosophy from Plato to Hegel. Today, dialectics must 'take place in the tension between insight into the whole impossible depiction of the right life and the consciousness of how things could be' (Adorno, 1973a: 133). This image underlies Adorno's thinking from the early inaugural lecture of 1931 to his philosophical master work, Negative Dialectics of 1966, which is among his thematically most complex and stylistically most difficult books. In Negative Dialectics Adorno claimed to have travelled across the ice desert of abstraction. This opus magnum reaches its peak with the twelve Meditations on Metaphysics, which are located at the outer peripheries of what philosophical reflection is 
capable. Here Adorno asks whether the idea of man's humanity can be saved in the face of the reality of death camps. Adorno opposes the historical fact of a failure of culture, a failure 'unquestionably proven' by Auschwitz, to Kant's expectation that freedom will realize itself in the transcendental subject and to Hegel's idea that reason will realize itself in world spirit. This moves Adorno to formulate a new categorical imperative: 'That Auschwitz never be repeated and nothing similar ever happen' (Adorno, 1973b: 365).

Adorno saw himself as someone whose path of radical-negative thought was dependent on the free space of nowhere. The zone between the boundaries, no-man's-land, had fascinated him since childhood. 'There I liked to while most under the pretense, which I in no way believed, that this realm belonged to no-one' (Adorno, 1997: 305). In this recollection, written down at the age of sixty, Adorno comes back to an old dream that everyone might be able to move equally freely in no-man's-land, that there differences might flourish equally. Adorno got his pictureless picture of the right life from this happy image of the unbounded yet mutually recognizing existence between borders: No-man's-land as the place of the non-identical. No-man'sland was the symbol of that place in which one could be different without fear, in which contradictions would coexist in their extremes, without already having to take one side or the other.

This paper was given as a talk to the Graduate/Faculty Seminar in Social and Political Thought at the University of Sussex on 19 February 2004.

Stefan Müller-Doohm is Professor of Sociology at the University of Oldenburg and is the author of Adorno: An Intellectual Biography (2003, trans. Rodney Livingstone 2005); and Habermas: A Biography (2014, trans. Daniel Steuer 2016).

\section{Endnotes}

${ }^{1}$ In a letter to Thomas Mann of 5 July 1948, giving information about his life, Adorno writes: 'I studied philosophy and music. Instead of deciding between them, I have had the feeling all my life that I was pursuing the same thing in the different domains.'

\section{Bibliography}

Adorno, T. W. (1973a) Philosophische Terminologie Vol. 1, Frankfurt: Suhrkamp 
Adorno, T. W. (1973b) Negative Dialectics (E. B. Ashton, trans.) London and New York: Routledge

Adorno, T. W. (1974) Minima Moralia: Reflections from Damaged Life (E. Jephcott, trans.) London: New Left Books

Adorno, T. W. (1992) Notes to Literature Vol. 2 (Shierry Weber Nicholson, trans.) New York: Columbia University Press

Adorno, T. W. (1992) Mahler: A Musical Physiognomy (E. Jephcott, trans.) Chicago: University of Chicago press

Adorno, T. W. (1997) Kulturkritik und Gesellschaft I, Gesammelte Schriften Vol. 10.1 Rolf Tiedemann et al. (eds.), Frankfurt: Suhrkamp

Benjamin, W. (1999) The Arcades Project (Howard Eiland and Kevin McLaughlin, trans., prepared on the basis of the German volume edited by Rolf Tiedemann) Cambridge MA: Belknap Press

Enzensberger, H. M. (1999) ‘Deutscher sein ist kein Beruf. Spaziergang durch die Zeit. Alexander Kluge im Gespräch mit Hans Magnus Enzensberger' DU: Die Zeitshrift der Kultur, No. 699

Gödde, C. and Sprecher, T. (eds.) (2002) Thomas Mann - Theodor W. Adorno: Briefwechsel 1943-55 Frankfurt: Fischer

Gödde, C. and Lonitz, H. (eds.) (2003a) Theodor W. Adorno: Briefe an die Eltern. Briefe Briefwechsel Band 5 Frankfurt: Suhrkamp

Gödde, C. and Lonitz, H. (eds.) (2003b) Theodor W. Adorno - Max Horkheimer, Briefwechsel, Band 1: 1927-37. Briefe und Briefwechsel Band 4.1 Frankfurt: Suhrkamp

Horkheimer, M. and Adorno, T. W. (1973) Dialectic of Enlightenment (John Cumming, trans.) London: Allen Lane

Horkheimer, M. (1996) Briefwechsel 1949-1973, Gesammelte Schriften Bd. 18, Gunzelin Schmid Noerr and Alfred Schmidt (eds.), Frankfurt: Fischer 